\title{
Sanitizing Jakarta
}

\section{decolonizing planning and kampung imaginary}

Putri, Prathiwi Widyatmi

Published in:

Planning Perspectives

DOI:

10.1080/02665433.2018.1453861

Publication date:

2019

Document version

Peer reviewed version

Citation for published version (APA):

Putri, P. W. (2019). Sanitizing Jakarta: decolonizing planning and kampung imaginary. Planning Perspectives, 34(5), 805-825. https://doi.org/10.1080/02665433.2018.1453861 
This is the author's postprint version of an article in Planning Perspectives, vol. 34, 2019, issue 5, pp. 805-825. The authoritative version can be found here: $\underline{\text { https://doi.org/10.1080/02665433.2018.1453861 }}$

The present research benefitted from funding from the European Research Council (ERC). ERC Grant: State Formation Through the Local Production of Property and Citizenship (Ares (2015)2785650 - ERC-2014-AdG - 662770-

Local State).

\title{
Sanitizing Jakarta: decolonizing planning and kampung imaginary
}

\author{
Prathiwi Widyatmi Putri
}

Department of Food and Resource Economics, University of Copenhagen, Rolighedsvej 25, 1958 Frederiksberg, Denmark

Email: pwp@ifro.ku.dk

Prathiwi was formally trained as an engineer architect and spatial planner. She has worked for development initiatives in Aceh, Java, and West Papua in Indonesia, as well as in Central Viet Nam, with varying multinational organizations.

Acknowledgements:

This article is based on my doctoral research at KU Leuven (2009-14), for which I received the generous support from the Vlaamse Interuniversitaire Raad/ University Development Cooperation (VLIR-UOS), as well as Dr. Teti Argo and Dr. Ibnu Syabri who hosted the fieldwork in 2011-12 at the Regions and Infrastructure Research Center, Institut Teknologi Bandung. A more recent fieldwork in Jakarta has been conducted in 2017, for the current postdoc at the University of Copenhagen that also allows me to further elaborate the topic and arguments in this article. I thank Frank Moulaert, Han Verschure, Adriana Allen, Kelly Shannon, Simone Tulumello, Penelope Anthias and Christian Lund, as well as the referees and editors of Planning Perspectives for their valuable suggestions. The content of the article and any remaining shortcomings are, of course, my responsibility. 


\section{Sanitizing Jakarta: decolonizing planning and kampung imaginary}

This article offers a critical view of the water and sanitation sector within the broader trajectory of Jakarta's spatial development and planning. Its territorial focus is on kampungs and it traces their historical journey from the periphery of the colonial city - Batavia and its modern planning domain - to the centre of the post-independence planning regime. 'Kampung' is an indigenous term for ruralagricultural settlements. In the colonial period, it was used to label non-European and non-Chinese settlements in and around the city. Colonial modernity created certain stigmatizations: kampungs came to be seen as undisciplined and insanitary communities, sources of insurgency and threats to public health. But the kampung realm was also (re)produced through practices of segregation within the colonial planning system. The imaginaries of colonial modernity linger on within today's planning practices, resulting in a persistent failure to improve the environmental health of kampungs and the city as a whole. Postcolonial kampungs remain as a cosmopolitan enclave open to different cultures and sociopolitical contestations. The article argues that, given the kampung's resilience in varying socio-ecological conditions, urban kampungs should be seen not as a problem, but as an opportunity for new planning approaches.

Keywords: urban sanitation; water management; urban planning; colonial modernity; community development; Jakarta; urban kampungs

\section{Introduction: kampung imaginaries}

In 2017, the sewerage service in Jakarta covered less than 5 per cent of the city area and the network's length has not even doubled since the present stage of construction began in $1983 .{ }^{1}$ Outside this system, various incremental solutions for handling wastewater exist, but do not necessarily comply with basic standards of environmental and personal health. Several masterplans for wastewater management have been formulated over the past four decades, unrealistically proposing a single model of centralized sewerage 
system for the vast and heterogeneous urban fabric. Meanwhile, small-scale interventions led by international organizations have introduced some models of community-based sanitation systems in informal settlements, from shared latrines to improved septic tanks. But they remain 'local' and insignificant compared to the scale of urban agglomeration and its socio-material complexities.

To explain these persistent failures in improving sanitary conditions in Jakarta, this article suggests a critical look at the historical trajectory of its spatial development and planning institutions. It questions everyday assumptions of 'planning', 2 especially those imposed on informal settlements, like urban kampungs in Jakarta. Different facets of informality in kampungs have been seen as sources of what Vanessa Watson calls 'clashes of rationalities' ${ }^{3}$ in their interplay with the modern planning sphere. There exists a view that the persistence of Jakarta's insanitary condition corresponds to the persistence of kampungs, whose communities have often been the target of evictions as they perform rationalities incompatible with those of the modern development paradigm. The incompatibility also complicates the modern binary of state and citizenship categorization, which cannot capture complex, multiple relations between the inhabitants and (colonial) rulers.

The Western planning trajectory has steered our imaginations regarding the positive role of the modern state in structuring planning reforms and radicalizations, regardless of what impacts they actually bring. ${ }^{4}$ The trajectory has not been devoid of conflicts, however, and this has raised questions over the role of planning as means of

2 Huxley, 'Historicizing Planning'.

3 Watson, 'Seeing from the South'.

4 Friedmann, Planning in the Public Domain. 
social control to ensure stability and growth. ${ }^{5}$ Although there is no singular concept of 'state'-and- 'citizenship' applicable to all Western countries, ideas of planning have been continuously questioned and redefined in relation to the existence of the sovereign (welfare) state and the idea of universal citizenship, allowing a planning approach that is more collaborative, communicative, and participative. ${ }^{6}$ The historical trajectory of modern planning in Jakarta is significantly different. It goes back to pre-nineteenthcentury colonial Batavia. Planning mainly consisted of water engineering that was coercive to the previously existing socio-ecological system. This engineering planning constituted the formulation of modern state itself. Planning determined the very basis of citizenship, but not every inhabitant could be defined as a 'citizen' since the formulation and implementation of policy were race-biased. Through planning, too, emerged several technical and managerial state institutions by means of which the lives of the population were regulated.

Creating spatial orders through geometric layouts - streets, gutters, railways, or homogeneous plantations - was the main governance technique during the early periods of colonization almost everywhere. ${ }^{7}$ While the rural productive sites had been organized, physical orders were also considered fundamental for turning the city into the lighthouse of colonial progress. But this objective was challenged by the 'intangible' urban diseases of the nineteenth century: malaria, tuberculosis, or water-borne intestinal

5 Hillier and Van Looij, 'Who speaks for the poor?'.

6 Huxley, 'Historicizing Planning'; Elling, 'Communicative Planning'; Lo Piccolo, 'Viewpoint. The planning research agenda'.

7 Bigon, 'Sanitation and street layout'; Home, Of Planting and Planning; Melosi, The sanitary city; Mitchell, Colonising Egypt. 
illness such as cholera. ${ }^{8}$ Countering contagious disease was the chief push factor in the integration of indigenous settlements within the colonial spatial development; the object was to sanitize the contaminating enclaves and thus ensure public health for all. ${ }^{9}$ This was also the case with the working-class neighbourhoods of Western industrial cities at the time. ${ }^{10}$ The danger of such urban calamities pushed modernization ever further, in both the 'home' countries and their colonies, with the introduction of city-wide piped water networks and underground sewers, together with the new mass consumption of domestic sanitary equipment. ${ }^{11}$

Advancing spatial orders in colonial cities was not a simple task, as so-called ‘informality’ persisted within the indigenous settlements, but the public spending policy also deliberately avoided a universal intervention for water infrastructure development by prioritizing 'white' settlements. ${ }^{12}$ Failures to deliver the sanitary city persist in the postcolonial Global South, and it could be argued that they fundamentally derive from the blinkered vision of a colonial planning system that failed to address the heterogeneous urban social-ecological materiality. ${ }^{13}$ In Southeast Asia the climate, with monsoons and higher rates of precipitation, also challenged the modern paradigm of land-based urban living introduced by the colonial planning practices. ${ }^{14}$ The guiding

8 McFarlane, 'Governing the Contaminated City'; Gandy, 'Planning, Anti-planning and the Infrastructure Crisis '; Abeyasekere and Owen, 'Death and Disease'.

9 Jewitt, 'Geographies of shit'; Bigon, 'Bubonic plague, colonial ideologies, and urban planning policies'.

10 Porter, The History of Public Health and the Modern State.

11 Gandy, 'The Paris Sewers and the Rationalization of Urban Space'; Kaika and Swyngedouw, 'Fetishizing the modern city'; Jewitt, 'Geographies of shit'.

12 See Bigon, 'Sanitation and street layout'; Kooy and Bakker, 'Splintered networks'.

13 See also Bigon, 'Bubonic plague, colonial ideologies, and urban planning policies'.

14 Schramm, 'Flooding the sanitary city'; Kop, 'Water in the city'. 
principle of this paradigm is to dry the city as soon as possible after a deluge of water, overlooking the functions of traditional wells as both systems of storm water storage and a clean water source. ${ }^{15}$

This article provides an informative history of Jakarta's massive failure to sanitize the city as a whole. It highlights the decline of the socio-ecological traditions of kampung communities in their interaction with twentieth-century urban planning in Batavia, the colonial city. The article aims, first, to elucidate the limits of the technocratic rational planning approach established in the Dutch colonial period; and, second, to inform studies of more recent urban development approaches from a standpoint that views kampungs as the city itself, rather than as an epitome of the nonmodern waiting to be developed by pursuing the trajectory of Western cities. ${ }^{16}$ The history of Batavia and postcolonial Jakarta has been well documented in other respects, ${ }^{17}$ but these two important questions have not been tabled.

Five sections follow this introduction. First, the article discusses typical sociospatial dynamics of the kampungs surrounding the port city of Batavia, before the city expansion in 1810. Second, I discuss the birth of spatial planning in relation to the twentieth-century rationalization projects carried out by the colonial government. The essence of kampung integration within the municipality and its planning system was merely the stark imposition of physical and behavioural orders that were entirely foreign to endogenous logics. Third, it is shown that in the first five decades of the postcolonial era, both planning and eviction remained an inseparable part of Jakarta's development cycle on its way to becoming a megacity. The investment direction for

15 See Jumsai, 'Urban Aquatics'.

16 See Roy, 'Urban Informality'; Robinson, 'Thinking cities through elsewhere'.

17 See for example Silver, Planning the Megacity; Abeyasekere, Jakarta: A history; Grijns and Nas, Jakarta- Batavia. 
large-scale property developments was broadly in step with the ambition to develop large-scale infrastructure systems, although these two aims were not necessarily coherent at all levels. Fourth, the article scrutinizes the current coexistence of incremental planning, unbundled sanitary service, and deteriorating environmental quality. Finally, a conclusion proposes the insight that collective community actions are crucial planning agencies if a sanitary and democratic Jakarta is to be achieved and maintained.

\section{The autochthonous kampungs and the walled city of Batavia}

Batavia grew from a small fort, originally an outpost providing logistical support to the Dutch trade company, VOC (Vereenigde Oostindische Compagnie). Wanting to establish a regional head office, VOC built the walled city of Batavia in 1619 by gradually destroying Jayakarta, a trading port of the Banten Sultanate. VOC mobilized slaves, workers, and regional traders from China and the so-called outer islands of the archipelago to construct and populate the new town. ${ }^{18}$

Pre-twentieth-century Batavia had two major spatial enclaves: the walled city housing Europeans and some elites from other races that predominantly comprised the technologies of colonial governmentality, and the surrounding kampungs, the socioeconomics of which were deeply embedded in ethnic traditions. The kampungs represented pre-colonial income structures in Java that were built on various subsistence production systems (fisheries, agriculture, and hunter-gatherer systems) linked to smallscale commerce based on isolated person-to-person transactions conducted in several 
market nodes. ${ }^{19}$ When Batavia was built, as well as the surrounding indigenous villages there had been enclaves where other Asian traders settled. Indigenous settlements emerged in the southern part and close to natural streams, relatively far from the walled city; communities preferred not to build housing on the low marshy land in the northern part, as they were unable to deal with natural flooding. ${ }^{20}$ They used the marshy lands for agriculture only. ${ }^{21}$

The colonial government actively influenced this spatial fragmentation. Sugar plantations expanded in the 1670s, generating an increasing influx of Chinese farmers and traders who settled outside the walls, beyond the close control of the city authorities. ${ }^{22}$ Kampung communities responded to the exclusion and oppression imposed by the colonial regime by living with or close to specific ethnic groups and maintaining traditional socio-economic networks. ${ }^{23}$ Indeed, their participation in the capitalist economy was limited to jobs that generated a very low income, and they were excluded from more strategic roles. ${ }^{24}$ As a result, these communities continued to rely on subsistence agriculture and fishing, working on their own or rented land, in between several (seasonal) jobs as labourers, 'coolies', and crafters. ${ }^{25}$ These traditional economic activities were manifested in heterogeneous working times and blurred borders between

19 Alexander and Alexander, 'Protecting Peasants from Capitalism'; Christie, 'States without cities'; Ray, 'Asian Capital'.

20 Putri and Sari, 'Jakarta Waterscape'.

21 Gunawan, Gagalnya Sistem Kanal [The Failure of Canal System].

22 Blussé, 'Batavia, 1619-1740'.

23 See Guinness, Kampung, Islam and State in Urban Java.

24 Elson, 'Sugar Factory Workers'; Booth, 'Living Standards and the Distribution of Income';

Ray, 'Asian Capital'; Alexander and Alexander, 'Protecting Peasants from Capitalism'. 25 See Booth, 'Living Standards and the Distribution of Income'; Elson, 'Sugar Factory

Workers'. 
working and living space. ${ }^{26}$ Subsistence agriculture made the kampungs greener and less dense than the walled city and its vicinity. Communities used surface water for washing and bathing. Agriculture and fishery activities in the kampungs kept the natural cycle of water functioning in people's immediate environment - their compounds. They had their wells and streams as well as water purification systems in the form of wetlands and other natural infiltration wells.

In the walled city, the Dutch colonists introduced a new urban culture; working space was clearly separated from the domestic world of social (re)production. Modern canals functioned for transporting goods to warehouses and factories, while brick houses built along the canals symbolized the modern domestic life of European workers and their families. ${ }^{27}$ Batavia was built to resemble 'its sister city', Amsterdam, adopting an 'offensive spirit' as it set out to engineer nature and so conquer it. ${ }^{28}$ The Dutch colonists introduced a new attitude towards water by occupying the marshy land in a way that was unfamiliar to Javanese traditions. Rivers were made straight and bordered by concrete walls, new canals were dug, and the excavated soil was used to erect foundations for buildings. ${ }^{29}$

But results were not as expected. Java's ecological setting was very different from that of the mother country, Holland. The canals did not function because precipitation was heavier and rivers carried thicker silts from higher areas; as a result,

26 See Christie, 'States without cities'; Waterson, The Living House; Reid, 'The Structure of Cities in Southeast Asia'.

27 See Veering, 'Nodes in the maritime network'.

28 Hooimeijer, 'Exploring the relationship between water management technology and urban design'.

29 Caljouw et al., 'Flooding in Jakarta'. 
the canals became blocked and filled the city with stagnant water. ${ }^{30}$ In 1733 , a malaria outbreak drove a substantial increase in mortality, from around 500 people (6-10 per cent of population) in the earlier years to more than 2,000 people. ${ }^{31}$ The walled city of Batavia came to be seen as a graveyard. Concerned for their health, rich people gradually left the city and moved to the southern areas. ${ }^{32}$ This gradual migration of the European population had already transformed the urban dynamics outside the walls before 1810, when the colonial government officially moved the town centre from Old Batavia to Weltevreden.

Many communities were evicted from existing kampungs to enable construction of the new centre in Weltevreden. Meanwhile, in rural areas across Java, subsistence agriculture land had been seized for export-crop plantations, causing forced migration to urban areas as people searched for new income sources. ${ }^{33}$ Over the nineteenth century, the whole of Java was brought under the control of Dutch colonists; this also led to a great influx of Javanese into Batavia, because indigenous populations were no longer considered a danger to political stability and thus no longer forbidden to live in the capital city. ${ }^{34}$ Batavia's remaining kampungs accommodated newcomers from rural areas and the evicted communities from demolished kampungs, and thus grew faster and became denser. The land available for household agriculture and fishery decreased, destroying community ecosystems. Poverty and the incidence of cholera increased in

30 Kop, 'Water in the city'.

31 Van der Brug, 'Unhealthy Batavia'.

32 Van der Brug, Ibid.; Abeyasekere and Owen, 'Death and Disease'.

33 Elson, 'Sugar Factory Workers'.

34 Abeyasekere, Jakarta: A history. 
the kampungs. ${ }^{35}$ But kampungs persisted within the segregated city of Batavia (see Figure 1).

Figure 1. A schematic transformation of kampungs in Batavia ca. 1740-1897-1935. Source: compiled by the author based on the maps of Batavia 1650 (Abeyasekere 1989), Batavia 1740, 1897 and 1935 (courtesy of KIT/ the Netherlands Royal Tropical Institute)

\section{The origin of planning: sanitizing the colonial city and disciplining urban life}

After the trade company, VOC, was liquidated in 1789 and nationalized by the Netherlands, Dutch colonialism in the East Indies (now Indonesia) started to be formalized and several governmental organizations were formed for and in the colonies. ${ }^{36}$ 'Nationalization' did not necessarily mean 'welfare in the colony', but growth. The first liberal policies were implemented as of 1870 , followed by a huge influx of Europeans to Batavia, and this also triggered several governmental changes and new development policies. ${ }^{37}$

Created in 1866, BOW (the Department of Public Works) became the leading colonial-era governmental agency specializing in water engineering. ${ }^{38}$ It developed large-scale water works that formed an important part of the colonial landscape, as they heralded developmental progress and reinforced Dutch identity. In the first half of the nineteenth century, the main purpose of water projects in Java was to increase sugar production under the forced cultivation system. ${ }^{39}$ However, the nature of engineering works changed over the rest of the century (see Figure 2). Concentrated demographic

35 See Booth, 'Living Standards and the Distribution of Income'; Elson, 'Sugar Factory Workers'.

36 De Jong and Ravesteijn, 'Technology and Administration'.

37 Kop, 'Water in the city'; Van Roosmalen, 'For Kota and Kampong'.

38 De Jong and Ravesteijn, 'Technology and Administration'.

39 De Jong and Ravesteijn, Ibid.; Ertsen and Ravesteijn, 'Living Water'. 
growth in cities also constituted a threat to public health. This led the state to shift the focus of engineering works from economic production alone to incorporate public health concerns. Sanitation became a crucial urban development issue in Java during the rest of the colonial era. The decentralization act of 1903 clearly stated that a municipality was responsible for ensuring quality public health and addressing new needs of housing and town expansion. ${ }^{40}$

Figure 2. The modern state and water engineering works in the Dutch East Indies Source: compiled by the author

A public water service was created in 1873 and, in the 1890s, pipelines were built to channel water into houses. ${ }^{41}$ Laying the pipe went slowly. By the 1920 s, only $119 \mathrm{~km}$ of water pipelines had been laid, serving around 4,000 inhabitants (less than 4 per cent of the total population); the beneficiaries were mainly Europeans and a small number of Chinese. ${ }^{42}$ The provision of clean water generated a significant reduction in water-borne diseases, ${ }^{43}$ but not among indigenous populations. ${ }^{44}$

Statistics and mapping were standard planning tools and these were used to declare the policy assumption behind the spatial distribution of water infrastructure networks. Native inhabitants were assumed to have a less-pressing need for water than other community groups. ${ }^{45}$ Table $\mathbf{1}$ shows estimated drinking water requirements in Batavia at that time. Many Javanese bathed collectively in public spaces designed for

40 Van Roosmalen, 'Expanding grounds'; Niessen, Municipal Government in Indonesia; Van Roosmalen, 'For Kota and Kampong'.

41 Kooy, Relations of Power, Networks of Water.

42 Kooy, Ibid.

43 A health report cited in Kop, 'Water in the city'.

44 Abeyasekere, Jakarta: A history.

45 See Kop, 'Water in the city'. 
both social and religious ceremonial functions, ${ }^{46}$ and this was taken to further imply that they did not want individual domestic connections. ${ }^{47}$ The policy makers did realize that different ethnic groups had different water consumption patterns, but this understanding merely served to legitimize the focus on meeting the needs of European populations while neglecting the preferences of others.

Table 1. Estimated Drinking Water Requirements in Batavia, 1890 Source: Kop, 2008

In the late nineteenth century, the engineer Van Breen developed an integrated network of canals and rivers that were designed for flood management, irrigation, flushing (to dispose of wastewater), and as clean water sources. This water network protected the inner city of Batavia in which the Europeans conducted various socioeconomic activities. Although water engineering was at the core of the technocratic planning in the earlier period of Batavia, the twentieth century saw stagnation in hopedfor progress towards solutions to the practical and material problems of wastewater disposal.

As the colonial government had addressed the need for clean water in Batavia by providing a centralized piped-water system, this naturally increased the volume of domestic wastewater. By the twentieth century, the government realized that depositing human waste in the ground or discharging it into open waterways was no longer sustainable. In 1910, flushing became BOW's second priority, after clean water provision, relegating irrigation and hydropower to lower priority levels. ${ }^{48}$ But flushing did not actually solve various environmental problems caused by chemical and faecal

46 Quinn, 'Washing Your Hair in Java'; Van Dijk, 'Soap is the Onset of Civilization'. 47 See Kooy, Relations of Power, Networks of Water. 48 Kooy, Ibid.; Kop, 'Water in the city'. 
pollutants, because it merely discharged wastewater into lower areas, affecting many (non-European) settlements that had no proper drainage systems. The government seemed reluctant to invest more in Batavia because a new colonial capital was planned at Bandung in the West Java highlands, although this plan was abandoned with the onset of the Second World War. ${ }^{49}$

The incremental technocratic approach during the colonial period failed to see Batavia as an entire ecosystem. Conveying clean water in and wastewater out from the core urban enclave were the main technological interventions in the absence of a conservation approach to environmental resources. There was no space within the governing system to think of innovations in addressing the physical-material cycles of water and sanitation. At that time in the wider context of the archipelago, nonanthropocentric, autochthonous water management systems had existed in Bali and certain coastal towns, but instead of being sources of inspirations for an embedded modernity they were seen as unproductive.$^{50}$ At the beginning of the new century, the colonial government embarked on social engineering aimed at the indigenous populations, relying on further advancement in its technologies of spatial organization; one effect of this was the resulting superiority of modern spatial planning over water engineering as a technical field. ${ }^{51}$

The election of a socialist government in the Netherlands brought the implementation of these so-called ethical policies in 1901, with decentralization as one

49 Silver, Planning the Megacity, 84.

50 See Lansing, 'Balinese "Water Temples" and the Management of Irrigation'; Lansing and de Vet, 'The Functional Role of Balinese Water Temples'; Widodo, Morphogenesis and Hybridity of Southeast Asian Coastal Cities.

51 Van Roosmalen, 'Expanding grounds'; ---, 'For Kota and Kampong'. 
of the main planks. ${ }^{52}$ Under these policies, it was considered that indigenous communities had to be involved in decision-making processes regarding development, and that, as their living conditions were significantly behind European standards, they needed external support to help them modernize..$^{53}$

Spatial planning was seen as a policy field through which indigenous communities could be disciplined into compliance with modern European ideals. ${ }^{54} \mathrm{New}$ architectural features - squares, monuments, and modernist public buildings - not only marked the new modern era visually, but also forced the indigenous population to engage in certain patterns of activity. For example, the traditional bazaar system that made the streets busy was not considered compatible with the image of modern urban life. The colonial government created walled markets to control the vendors and compel them to adopt modern sanitary behaviour. ${ }^{55}$

Various housing projects were launched. The new housing complexes, especially Menteng, became the first target for the expansion of the piped water network. ${ }^{56}$ The garden city movement influenced Batavia and design proposals from prominent Dutch architects in the South. ${ }^{57}$ But trees were seen as 'rural' and hence not modern, ${ }^{58}$ so were cut down to enable an unobstructed view of the buildings that now formed the landmarks of the modern city. ${ }^{59}$ This brought further socio-ecological ruptures to kampungs as colonial planners overlooked the fact that urban trees had

52 Niessen, Municipal Government in Indonesia.

53 Kusno, Behind the postcolonial.

54 ---, 'Urban Pedagogy'.

55 Kunto, Semerbak Bunga di Bandung Raya; Kusno, 'Urban Pedagogy'.

56 See Kooy and Bakker, 'Splintered networks'.

57 See Van Roosmalen, 'Expanding grounds'; Harjoko, Urban Kampung.

58 See Reid, 'The Structure of Cities in Southeast Asia '.

59 Kusno, 'Urban Pedagogy'; Van Roosmalen, 'For Kota and Kampong'. 
played a vital ecological role in storing the ground water used by communities. A satellite town in Kebayoran, executed only in 1948 or three years after independence, was designed at the expense of a real garden consisting of thousands of fruit trees owned by communities. ${ }^{60}$

In comparison with the nineteenth century, the first half of the twentieth saw even greater rural to urban migration. In addition, inside the city, migration continued due to evictions from urban kampungs. ${ }^{61}$ Although new European residents had access to formal housing, there was a considerable lack of affordable housing for Indonesians. Urban kampungs provided the only option.

Under the influence of ethical policies, the Kampung Verbetering (kampung improvement) programme was launched. It aimed to improve roads, pathways, and drainage. There were three main reasons why the colonial government was willing to improve kampungs. First, nationalist and socialist members of the city council urged improvement of living conditions for non-Europeans. ${ }^{62}$ Second, kampungs were growing extensively in between European-occupied areas, and constituted a potential source of water-borne diseases. Third, kampungs were seen as enclaves of resistance and struggle against colonial rule. ${ }^{63}$ The municipality was forced to abolish the autonomous status of the village and, in many cases, the improvement programme was implemented on condition that kampungs renounced their autonomy. ${ }^{64}$

To ensure the success of its Verbetering initiative, the national government provided the city council with political and financial assistance to buy and manage land

60 Gunawan, Gagalnya Sistem Kanal; Harjoko, Urban Kampung.

61 Van der Heiden, 'Town planning in the Dutch Indies'.

62 Abeyasekere, Jakarta: A history.

63 Kusno, 'Urban Pedagogy'.

64 See Reerink, Tenure security for Indonesia's urban poor. 
from indigenous communities whose autonomy had been renounced. ${ }^{65}$ However, much of this state-acquired land was then used for European residences, constructed by private firms ${ }^{66}$ Following protests from many activists, a programme of modern public housing for the poor was launched. This programme was far from successful in meeting the needs of target groups because house prices remained too high. ${ }^{67}$

In 1918, the government built 100 public bathing places and 15 public washing points in the kampungs. ${ }^{68}$ However, such intervention was insufficient to meet the overall demand in the kampungs. The majority of inhabitants with a lower social status maintained the tradition of washing and bathing in public areas, along the canals and/or around public hydrants. Figure 3 shows communities washing with water from the main canals along the boulevards of Batavia, despite its poor quality. The spread of modern religions had actually caused public bathing to be seen as embarrassing ${ }^{69}$ but kampung communities had no access to improved facilities. Since the government moved the town centre to Weltevreden in 1810, urban life in the new Batavia was no longer structured according to water - the canals - but according to squares and roads. Water bodies became public spaces for the poor only, and thus they were the first to be exposed to the calamities caused by unsanitary conditions in Batavia.

Figure 3. Washing in Molenvliet, ca. 1936

Source: courtesy of KITLV/ Royal Netherlands Institute of Southeast Asian and Caribbean Studies

65 Niessen, Municipal Government in Indonesia.

66 See Harjoko, Urban Kampung; Van Roosmalen, 'Expanding grounds'

67 Abeyasekere, Jakarta: A history.

68 Kop, 'Water in the city'.

69 See Taylor, 'Bathing and Hygiene'. 


\section{Postcolonial urban development: large-scale ambitions}

During Sukarno's Orde Lama or Old Order (1945-66), spatial planning was meant to be a field to construct a new history that severed connections with the Dutch cultural and political systems. But despite its efforts to obliterate the collective memories associated with colonialism, Sukarno's administration chose to further the development of what had been conceived as modern before independence. The spatial development approach kept promoting road-orientated physical development along the North-South axis. Orde Lama also continued the late-colonial era traditions of celebrating collective consciousness in public squares. Several heroic monumental sculptures and iconic buildings were erected in public areas, to reinforce public consciousness of a unified, awakening nation. ${ }^{70}$

It was ironic that the people who were considered to constitute the very heart of the revolution for independence were evicted from the urban kampungs where they lived to make room for the development of new civic buildings and public spaces. ${ }^{71}$ No significant efforts were made to improve living conditions in kampungs, as most of the available budget went to large-scale construction projects. But people's welfare was modelled upon several social housing plans. ${ }^{72}$ Possibly influenced by the socialist and communist countries, the government pursued a utopia of turning all of the kampungs into formally planned settlements.

The modernist housing projects were inherited by President Suharto and his militaristic regime, Orde Baru or New Order (1966-1999). Not all housing proposals were implemented. When they were, the projects merely added 'new units at a fraction

70 Kusno, Behind the postcolonial.

71 See Harjoko, Urban Kampung; Van Roosmalen, 'Expanding grounds'. 72 ---, 'For Kota and Kampong'. 
of the pace of overall metropolitan population growth', ${ }^{73}$ and for the most part did not benefit poor communities. ${ }^{74}$ The Suharto government conducted a significant urban restructuring process following the fall in oil prices in 1982; this caused investment to shift to property development and amenities for growing middle-income groups. ${ }^{75}$ Both in inner and peripheral areas of the city, many residential areas including kampungs were rapidly developed into commercial, office, and condominium districts. ${ }^{76}$

The decline of kampungs amid community evictions became necessary metabolic events for the growth of the capital city. But at the same time kampungs became a focus in the Suharto era, thanks to Governor Ali Sadikin's vision of improved social conditions for Jakarta. Kampungs were an important core of development as the communities constituted the mass population targeted for nation building and the new development order. The colonial attempt to improve kampungs was considered successful by the Governor; he now targeted kampungs for improving the capital city because, first, at the time they constituted 60 per cent of the Jakarta area, and second, in this way the socio-physical gaps between kampungs and the commercial areas could be mitigated by utilizing a relatively small share of the development budget. ${ }^{77}$ The postcolonial Kampung Improvement Program (hereafter KIP) was launched in 1969 by the Jakarta administrative government and maintained until 1978. It managed to

73 Silver, Planning the Megacity, 126.

74 Harjoko, Urban Kampung; Gunawan, Gagalnya Sistem Kanal.

75 This topic has been sufficiently written by Firman, 'Urban development in Indonesia, 19902001 '; Goldblum and Wong, 'Growth, crisis and spatial change'; Rimmer and Dick, The City in Southeast Asia; Silver, Planning the Megacity.

76 Firman, 'Urban development in Indonesia'; Goldblum and Wong, 'Growth, crisis and spatial change'.

77 See Silver, Planning the Megacity, 126-53. 
improve 5,743 hectares of land and benefited 2.4 million people. ${ }^{78}$ In 1974-1982 the national government, with support from the World Bank, extended the programme in Jakarta and exported it to other cities as the capital city could claim a success story. By 1979, the KIP had benefited about 3.3 million Jakarta residents, representing over 70 per cent of the city's estimated slum population at that time. ${ }^{79}$

But the Orde Baru economic development strategy, with its mega-scale construction projects, also meant that kampung evictions were even more frequent. Although had benefited from the KIP, the kampungs in Kuningan and Kebon Kacang were demolished to provide space for commercial development. This was not without precedent. Several kampungs improved during the colonial era had also vanished during Orde Lama,${ }^{80}$ but such fatal reversals were not anticipated by the Jakarta government. The KIP could not offer a panacea to Jakarta that kept receiving population influxes while pursuing its ambition to be a world city. Already by the end of 1979 , the total area covered by kampungs that had been cleared to make way for post-independence development projects was larger than the total area covered by kampungs improved earlier under KIP (see Figure 4).

Figure 4. The twentieth century improved kampungs and urban development Source: Compiled and redrawn by the author, based on the study by Harjoko (2009) and Van Roosmalen (2005), Jakarta Masterplan 1965, Batavia 1897 \& 1935 (KIT collections, the Netherlands), Batavia 1959 (US Army Map Service collection), as well as 'improved kampungs and kampungs to be improved in Jakarta' (Verschure 1979)

78 See Bianpoen, 'Jakarta's Poor'.

79 Werlin, 'The Slum Upgrading Myth'; Verschure, Housing and development.

80 Harjoko, Urban Kampung. 
It wasn't only violent evictions that caused Jakarta's kampungs to perish. The KIP could not sustain communities in the kampungs because it failed to offer any solutions to underlying structural problems regarding access to land and housing. As in the colonial era, the KIP caused land prices in the improved kampungs to increase. In consequence, many landowners sold their land or increased the rent, which forced many tenants to move to other kampungs in the urban periphery. ${ }^{81}$

Large-scale property development projects had driven the needs of investment in large-scale infrastructure projects, and vice versa. In 1985, the nation-wide Integrated Urban Infrastructure Development Programme (IUIDP) was launched by the Ministry of Public Works, to address infrastructural needs of the whole urban system. ${ }^{82}$ It was also pushed for efficiency and effectiveness of (international) public investment, responding to the previous infrastructure development processes that were considered project-oriented, focused on short-range needs, and dedicated only to particular infrastructure problems in isolated project areas. ${ }^{83}$ With IUIDP, foreign aid was expected to be synergized with other sources of funding, such as national and provincial public resources. Spatial planning was instrumentalized for guiding (future) infrastructure investment and attracting private sector involvement.

The IUIDP included the KIP scheme to correct its scalar approach, because KIP was meant to improve sanitary conditions in the kampungs in the absence of technical plans for developing wastewater management systems at the neighbourhood level and beyond. ${ }^{84}$ But within the IUIDP implementation, sanitation development including wastewater management was the lowest priority among all elements of IUIDP, with the

81 Abeyasekere, Jakarta: A history.

82 See also Hoff and Steinberg, 'The Integrated Urban Infrastructure Development Programme'. 83 Mattingly and Winarso, 'Urban Spatial Planning and Public Capital Investment'. 84 See Hoff and Steinberg, Op. cit. 
major funding allocated for road construction, followed by drainage, clean water provision, and solid waste management. Wastewater typically received less than five per cent, while drainage received up to 20 per cent of the investment. ${ }^{85}$

It was around the period of IUIDP that the national government constructed Jakarta's sewerage and wastewater treatment plant, following the first wastewater masterplan in 1977. However, only a small part of the masterplan was implemented, to form the major part of the state sewerage system in $2017 .{ }^{86}$ After the IUIDP, the masterplan has been revised three times: in 1991, 2001, and 2005. The scope of the 1991 document goes far beyond the first masterplan. It studied the whole area of Jakarta and proposed a project execution covering more than 16,000 ha of sewerage network. ${ }^{87}$ This plan was not implemented. Another plan was developed in 2001. The document concentrated on the previous prioritized area in the centre and proposed a smaller centralized system in the northern area. In 2005, an action plan to implement the 2001 document was designed, and followed by at least two detailed engineering plans in 2007 and 2009. ${ }^{88}$ But, up to the following decade, no significant sewer extension was made.

In the meantime, in addition to the earlier governance technique of architectural modernization, a new development slogan was created. To enhance the economic and spatial development strategies of Orde Baru, Governor Wiyogo (1987-1992) launched the slogan 'BMW', promoting Jakarta as Bersih Manusiawi berWibawa (Clean, Humane, Respectable). The slogan was associated with an image of Jakarta that was intended to attract foreign investment and the 'BMW class', as well as an alliance

85 Miller, 'Support to DKI Jakarta for Wastewater Management'.

86 Yachiko Engineering, The Project for Capacity Development. Updated in the author's interview 2017

87 JICA, The Study of Urban Drainage and Wastewater Disposal Project. 88 PDPAL Jaya, Rencana Strategi Sanitasi Kota Provinsi DKI Jakarta Tahun 2010-2015. 
between politicians, a strong executive, and the business community ${ }^{89}$ During Orde Baru, modern living was also associated with consumption patterns like those espoused by American suburban lifestyles: cars, single-family landed houses, and shopping malls. The use of the term 'Humane' in the slogan was an effort to build an image of sociopolitical stability and equity that did not actually reflect the truth, considering the social unrest caused by the scale of evictions. The 'Clean' image had actually been developed earlier by Suharto, to promote a nation that was free of the communist ideology that grew during Sukarno's rule. ${ }^{90}$ The terminology was also used to create an impression of a new modern Jakarta: clean streets without street vendors or becak (three-wheeled rickshaws).

The militaristic Suharto regime also introduced the concept of security, placing guards in commercial and business districts to show that Jakarta was a place of order. Residents were expected to behave in a disciplined manner in the public (consumptive) space that had been created inside buildings (e.g. shopping malls), instead of in the open public spaces associated with Sukarno and the people's movements. ${ }^{91}$ Indoor 'public' space could protect those able to pay for this privilege from pollutants outside. At the same time, canals along the main boulevards were no longer used for washing and bathing, as the kampungs disappeared from the inner city and strict regulations were enforced to keep the main districts free from the activities of the poor.

\section{The twenty-first century Jakarta: contested imaginaries}

Under Orde Baru development strategies, Jakarta has been enhanced into sites of

89 Leaf, 'Building the road for the BMW'.

90 Kusno, 'Guardian of Memories'.

91 See Kusno, Ibid.; ---, 'The Appearances of Memory'. 
consumption. ${ }^{92}$ Several incongruences and contradictions emerge from this. While the city has provided the public sphere in which imposing new orders and rationalities can flourish, the domestic sphere cannot escape from the regularization and rationalization required by the new consumption pattern. While meeting basic needs has become more commodified, in general, communities have been increasingly vulnerable to the absence of cheap and reliable water and sanitation services. ${ }^{93}$ Individual households struggle to survive at this most basic level, let alone the broader requirements of a healthy environment or the state-encouraged expectation to live in neighbourhoods that comply with the new metropolitan visual aesthetic. But bulldozing dilapidated kampungs also incurred the risk of cutting off at source the flow of inhabitants that sustained the country's low-cost labour markets. Jakarta's economic growth continually fuelled a strong demand for cheap labour ${ }^{94}$ and historically urban kampungs have provided the sites where low-income populations found affordable access to housing and food while maintaining jobs in the city. ${ }^{95}$

While planning continued to fail to address the positive existence of kampungs, another wastewater masterplan was produced in 2012 proposing 15 zones of large-scale sewerage networks. ${ }^{96}$ This was seen as an improved concept, seeking to divide the growing urban area instead of attempting to engineer it into a single centralized system as in earlier masterplans. But the politics of large-scale investment is never simple; in an example from the 1990s, disagreements between the provincial legislation body and the

92 See for example Hogan and Houston, 'Corporate Cities'; Bunnell, 'Jakarta in Post-Suharto Indonesia'.

93 See Kooy et al., 'Inclusive development of urban water services in Jakarta'.

94 See Mulyana, Decent work in Jakarta.

95 URDI and Mercy Corps, Urban Bulletin No.2.

96 Yachiko Engineering, The Project for Capacity Development. 
national government had led to the cancellation of investment for sewerage expansion projects. ${ }^{97}$ While the political atmosphere does not seem to change, laying sewer pipes underground is technically very complex. A section head of Jakarta's water agency was very sceptical about the proposed zones of large-scale sewerage systems, because in each zone much of the land has been developed informally and incrementally, generating irregular patters that are seldom congruent with the grid patterns for piping the city. ${ }^{98}$

Surprisingly, the government has been granting developers the right to build housing estates without forcing them to provide proper environmental management systems. ${ }^{99}$ Road-oriented urban expansion to the south of Jakarta has been congested by the presence of large-scale private estates on land originally set aside for groundwater recharge and community agricultural land. ${ }^{100}$ A senior planner who was involved in one of the estate developments explained that developers acquired the land by buying the so-called lahan tidur or sleeping land - unproductive agricultural sites on the periphery of Jakarta - instead of evicting kampungs. ${ }^{101}$ But such legitimating discourse is not free from contestation. In a public meeting held by an NGO and involving experts and academicians, a researcher explained that in different ethnic traditions letting the land

97 Author's interview with several government officials: staff of Technical Division PD PAL Jaya, 2011; former financial director of PD PAL Jaya, 2011; Head of Division of Wastewater Ministry of Public Works, 2011; former director of Directorate of Environmental Sanitation Development, Ministry of Public Works, 2012

98 Author's interview, 2017

99 Author's interview with an employee of the environmental agency 2010; and with a secondechelon official at the spatial planning agency 2012

100 See also Hudalah and Firman, 'Beyond property'. 101 Author's discussion with the planner 2015 
lie fallow was a conscious strategy to regain land fertility; unfortunately, such community wisdom had been ignored. ${ }^{102}$

Increasingly, many Jakarta inhabitants ignore the fact that living in a wet coastal lowland area requires certain collective behaviours for tackling water-related problems on an everyday basis; these demands are very different from the situation to which one grows accustomed when living in a dry land. Coastal land reclamation and commercialization for exclusive waterfront development keep blocking public access to the sea. The most recent national development strategy for coastal areas involves foreign investments to fund 2,700-hectare land reclamation projects along Jakarta Bay. This mega project has been justified as a necessary step in self-funding another largescale infrastructure, the great sea wall designed for protecting the capital city from sealevel rise, without burdening the state's expenditure. Both projects are highly controversial as social and environmental costs are escalating. Fishing communities have reported to civil society organizations that existing islands in northern areas of the Bay have been destroyed due to sand mining. Furthermore, the waterfront development has evicted several traditional (fishing-based) kampungs, adding to the long list of forced evictions in the capital city.

The Jakarta Legal Aid Institute (LBH Jakarta) has reported that in 2015 alone there were 113 cases of forced evictions in Jakarta, directly affecting more than 8,000 households. ${ }^{103}$ These evictions occurred without prior meetings with communities or a search for consensus or alternative approaches from the technocrats who have been working with grassroots organizations. ${ }^{104}$ In half of the eviction cases, the government

102 Discussion at a public meeting attended by the author in a university in Jakarta, 2015 103 Januardy and Demadevina, Atas Nama Pembangunan [In the Name of Development]. 104 See also Ng, 'Intellectuals and the production of space'. 
has used environmental protection as the rationale for the land clearance, arguing that the evictions are inevitable to provide more 'green spaces' along the rivers, canals, and flood-ponds, with the overarching intention of reducing flooding. But the space along the rivers gained through the evictions has now been turned into concrete roads channelling mobility and access to property developments. ${ }^{105}$

Thanks to the fall of the Suharto regime, several independent water engineers have used their new-found freedom of speech to condemn the Jakarta government for having failed to provide a comprehensive yet realistic technical plan for overcoming its acute environmental problems (statements at several open meetings attended by the author in 2015-16). Sanitation has been the most marginalized infrastructure sector since the colonial era. As a result, the groundwater body has become highly polluted and depleted, and the rivers are no longer reliable sources of clean water because 85 per cent of the grey water produced in the city remains untreated. ${ }^{106}$ Most people have been living without access to basic water and sanitation services provided by the state, while the estuary city of Jakarta remains prone to flooding. Unjustly and irrationally, different ruling regimes over many decades have accused the poor who live in the river basin areas of being the cause of flooding and urban insanitary conditions, and made this spurious charge the legitimate and effective means of evicting them.

\section{Conclusion: the persistence of kampungs and the search for a new planning agency}

Postcolonial governments in Jakarta have kept the urban environmental sector outside the primary focus of public sector concern. Water and sanitation have been handled

105 Author's field survey 2017

106 Author's estimation based on Miller, Support to DKI Jakarta. 
only as household needs. Little attention has been paid to environmental sanitation issues at neighbourhood and city levels. Over a century after modern spatial planning was first introduced into Indonesia, environmental sanitation management still fails to respond to the specific biophysical characteristics of a coastal urban agglomeration. The various intertwining historical trajectories of different socio-political and economic systems contribute to the failure, but also open up an alternative future. The search is still on for a governing environment capable of delivering an improved urban hydrological cycle and well-delivered public health services.

Not only has no significant effort been made to build a basic infrastructure for providing services to kampung communities, but the urban poor have also been facing the constant threat of eviction. Kampungs have been seen as needing to be brought under control and integrated into the city's wider socio-spatial arrangement; certain ideals could be imposed upon them, but at the same time they were deemed to be underdeveloped sites that needed to be removed from the modern urban landscape and replaced by buildings and amenities for accommodating profitable economic activities. In the absence of welfare policies, kampung communities are not treated as united entities with certain rights, but as groups of self-responsible individuals.

No single attribute can explain what a kampung is. It is not a village; it is not a slum yet it lacks basic sanitary infrastructures; it is an organic settlement with a mixed socio-economic composition. ${ }^{107}$ To speak of kampungs is to speak of a heterogeneous whole, because each entity has a distinguishable historical trajectory. Perhaps the transgressive persistence of the kampung requires us to see them as the city itself. While often categorized as informal settlements and seen as objects to modernize, kampungs as both social and ecological entities possess certain kinds of self-governing order. And 
indeed, there are many other structural problems of the city - such as social-economic reproduction mechanisms entailing massive environmental destructions - that are too complex for the communities to tackle.

Today, communities are still far from able to solve their environmental problems, because of inaccessible costs, lack of capability to organize the necessary collective actions, and inadequate state protection of community reciprocity networks. Mechanisms that kampung community members once used to face crises collectively have now been lost, and their territorially embedded socio-ecological institutions have been disrupted. In the pre-modern era, communities had some degree of autonomy when it came to organizing their productive landscape. Within traditional agricultural communities, water was considered to be both a common productive good and an element of the ecosystem that was vital for the (re)production of the society. Certain practices, inherited from agricultural society, are still applied in many kampungs, like discharging wastewater into open water bodies and using river water for washing, although the quality of river water does not meet health standards. Neither of these practices are 'best', nor are the current incongruent practices of formal spatial planning and development systems in Jakarta. But perhaps nurturing community practices instead of diminishing them could lead to different and positive outcomes.

A universal right to water and sanitation does not necessarily require a uniform way of providing and accessing the services. As there will always be 'a multiplicity of population groups', it is only logical to draw on 'multiple and flexible policies' that leverage 'multiple techniques of administration' that can be tailored to different characteristics of territorialized communities. ${ }^{108}$ There have been calls for research, especially in the informal cities of the Global South, to find ways towards better 
systems of community self-management, both for meeting basic household water and sanitation needs and for managing the local environment and resources. ${ }^{109}$ It has been strongly argued that policy makers should see communities as groups of active citizens who are able to design and control their own service provisions, and neighbourhoods as sites for coordinating and deploying collective action for urban improvement. ${ }^{110}$ If the state expects communities to provide solutions for their environmental problems, it must protect their reproductive socio-economic activities.

\section{Bibliography}

Abeyasekere. Jakarta: A history. (Revised edition. Singapore: Oxford University Press, 1989).

Abeyasekere and Owen, "Death and Disease in Nineteenth Century Batavia," in Death and Disease in Southeast Asia. Explorations in Social, Medical, and Demographic History (Singapore: Oxford University Press, 1987).

Alexander and Alexander, "Protecting Peasants from Capitalism: The Subordination of Javanese Traders by the Colonial State," Comparative Studies in Society and History 33, no. 2 (1991): 370-94.

Allen, et al., "The peri-urban water poor: citizens or consumers?," Environment and Urbanization 18, no. 2 (2006): 333-51.

Bianpoen, "Jakarta's Poor: A Search for Solution," in Untuk Apa? Untuk Siapa? Rangkaian Pemikiran Lingkungan Berkelanjutan (Jakarta: UPH Press, 2011).

Bigon, "Sanitation and street layout in early colonial Lagos: British and indigenous conceptions, 1851-1900," Planning Perspectives 20, no. 3 (2005): 247-69.

Bigon, "Bubonic plague, colonial ideologies, and urban planning policies: Dakar, Lagos, and Kumasi, ," Planning Perspectives 31, no. 2 (2016): 205-26.

109 Hardoy et al., 'Governance for water and sanitation services'; Mara and Alabaster, 'A new paradigm'.

110 Allen et al., 'The peri-urban water poor '. 
Blussé, "Batavia, 1619-1740: The Rise and Fall of a Chinese Colonial Town," Journal of Southeast Asian Studies 12, no. 1 (1981): 159-78.

Booth, "Living Standards and the Distribution of Income in Colonial Indonesia: A Review of the Evidence," Journal of Southeast Asian Studies 19, no. 2 (1988): 310-34.

Bunnell, "Jakarta in Post-Suharto Indonesia: Decentralisation, Neo-liberalism and Global City Aspiration," Space and Polity 15, no. 1 (2011): 35-48.

Caljouw, et al., "Flooding in Jakarta. Towards a blue city with improved water management," Bijdragen tot de Taal-, Land-, en Volkenkunde (BKI) 161, no. 4 (2005): 454-84.

Chatterjee. The Politics of the Governed. Reflections on Popular Politics in Most of the World. (New York: Columbia University Press, 2004).

Christie, "States without cities; Demographic trends in Early Java," Indonesia 52(1991): 23-40.

De Jong and Ravesteijn, "Technology and Administration. The rise and development of Public Works in the East Indies," in For Profit and Prosperity: The Contribution made by Dutch Engineers to Public Works in Indonesia 1800-2000, ed. Ravesteijn, W. and J. Kop (Zaltbommel and Leiden: Aprilis and KITLV, 2008).

Elling, "Communicative Planning as Counter-Power," International Planning Studies Published Online 14 November 2016(2016).

Elson, "Sugar Factory Workers and the Emergence of 'Free Labour' in NineteenthCentury Java," Modern Asian Studies 20, no. 1 (1986): 139-74.

Ertsen and Ravesteijn, "Living Water. The development of irrigation technology and waterpower," in For Profit and Prosperity: The Contribution made by Dutch Engineers to Public Works in Indonesia 1800-2000, ed. Ravesteijn, W. and J. Kop (Zaltbommel and Leiden Aprilis and KITLV, 2008).

Firman, "Urban development in Indonesia, 1990-2001: from the boom to the early reform era through the crisis," Habitat International 26, no. 2 (2002): 229-49, http://www.sciencedirect.com/science/article/B6V9H-44HTNSH1/2/a001c9d36c60ee166dd74259d84f0c75.

Friedmann. Planning in the Public Domain: From Knowledge to Action. (New Jersey: Princeton University Press, 1987).

Gandy, "The Paris Sewers and the Rationalization of Urban Space," Transactions of the Institute of British Geographers 24, no. 1 (1999): 23-44. 
---, "Planning, Anti-planning and the Infrastructure Crisis Facing Metropolitan Lagos," Urban Studies 43, no. 2 (2006): 371-96.

Goldblum and Wong, "Growth, crisis and spatial change: a study of haphazard urbanisation in Jakarta, Indonesia," Land Use Policy 17, no. 1 (2000): 29-37.

Grijns and Nas, eds., Jakarta- Batavia. Socio-cultural Essays (Leiden: KITLV Press, 2000): Pages.

Guinness. Kampung, Islam and State in Urban Java. (Singapore: NUS Press, 2009).

Gunawan. Gagalnya Sistem Kanal. Pengendalian Banjir Jakarta dari Masa ke Masa [The Failure of Canal System. To Engineer Flooding in Jakarta, Policies across Time]. (Jakarta: Kompas, 2010).

Hardoy, et al., "Governance for water and sanitation services in low-income settlements: experiences with partnership-based management in Moreno, Buenos Aires," Environment and Urbanization 17, no. 1 (2005): 183-99.

Harjoko. Urban Kampung: Its Genesis and Transformation into Metropolis, with particular reference to Penggilingan in Jakarta. (Saarbrücken: VDM Verlag Dr. Müller, 2009).

Hillier and Van Looij, "Who speaks for the poor?," International Planning Studies 2, no. 1 (1997): 7-25.

Hoff and Steinberg, "The Integrated Urban Infrastructure Development Programme and Urban Management Innovations in Indonesia. IHS Working Paper Series No. 7," in IHS Working Papers Series (Rotterdam: Institute for Housing and Urban Development Studies (IHS), 1993).

Hogan and Houston, "Corporate Cities - Urban Gateways or Gated Communities Against the City? The Case of Lippo, Jakarta," in Critical Refelctions on Cities in Southeast Asia, ed. Bunnel, T., et al. (Singapore: Times Academic Press, 2002).

Home. Of Planting and Planning: The making of the British colonial cities. (London: E \& FN Spon, 1997).

Hooimeijer, "Exploring the relationship between water management technology and urban design in the Dutch polder cities," in Water and Urban Development Paradigms: Toward an Integration of Engineering, Design, and Management Approaches, ed. Feyen, J., et al. (London: Taylor and Francis Group, 2009).

Hudalah and Firman, "Beyond property: Industrial estates and post-suburban transformation in Jakarta Metropolitan Region," Cities 29(2012): 40-8. 
Huxley, "Historicizing Planning, Problematizing Participation," International Development Planning Review 37, no. 5 (2013): 1527-41.

Lembaga Bantuan Hukum Jakarta [the Jakarta Legal Aid Institute]. URL http://www.bantuanhukum.or.id/web/wp-content/uploads/2016/02/LaporanPenggusuran-2015_LBHJ_web.pdf accessed 05 October 2016, Atas Nama Pembangunan: Laporan Penggusuran Paksa di Wilayah DKI Jakarta Tahun 2015 [In the Name of Development: A Report on Forced Evictions in the Jakarta Province Administrative Area in 2015]. Jakarta, 2016.

Jewitt, "Geographies of shit: Spatial and temporal variations in attitudes towards human waste," Progress in Human Geography 35, no. 5 (2011): 608-26.

JICA, The Study of Urban Drainage and Wastewater Disposal Project in the City of Jakarta, Feasibility Study - Main Report (Jakarta: The Government of Indonesia, 1991).

Jumsai, "Urban Aquatics," in Water and Urban Development Paradigms, ed. Feyen, J., et al. (London: Taylor and Francis Group, 2009).

Kaika and Swyngedouw, "Fetishizing the modern city: the phantasmagoria of urban technological," International Journal of Urban and Regional Research 24, no. 1 (2000): 120-38.

Kooy, "Relations of Power, Networks of Water: Governing Urban Waters, Spaces, and Populations in (Post)Colonial Jakarta," (PhD Thesis, The Faculty of Graduate Studies, Geography, the University of British Columbia, Vancouver, Canada, 2008).

Kooy and Bakker, "Splintered networks: The colonial and contemporary waters of Jakarta," Geoforum 39, no. 6 (2008): 1843-58.

Kooy, et al., "Inclusive development of urban water services in Jakarta: The role of groundwater," Habitat International xxx(2016): 1-10, In Press, Corrected Proof, Available online 24 October 2016.

Kop, "Water in the city: Drinking water, sanitation and flood control in urban areas," in For Profit and Prosperity: The Contribution made by Dutch Engineers to Public Works in Indonesia 1800-2000, ed. Ravesteijn, W. and J. Kop (Zaltbommel and Leiden: Aprilis and KITLV, 2008).

Kunto. Semerbak Bunga di Bandung Raya (Bandung: Granesia, 1986).

Kusno. Behind the postcolonial: architecture, urban space, and political cultures in Indonesia. (London: Routledge, 2000).

---, "Guardian of Memories: Gardu in Urban Java," Indonesia 81, no. April (2006): 95149. 
---. The Appearances of Memory. Mnemonic Practices of Architecture and Urban Form in Indonesia. (Durham and London: Duke University Press, 2010).

---, "Urban Pedagogy. The Appearance of Order and normality in Late Colonial Java, 1926-42," in The Appearences of Memory. Mnemonic Practices of Architecture and Urban Form in Indonesia (Durham and London: Duke University Press, 2010).

Lansing, "Balinese 'Water Temples' and the Management of Irrigation," American Anthropologist New Series, 89, no. 2 (June) (1987): 326-41.

Lansing and de Vet, "The Functional Role of Balinese Water Temples: a Response to Critics," Human Ecology (2012).

Leaf, "Building the road for the BMW: culture, vision, and the extended metropolitan region of Jakarta," Environment and Planning A 28(1996): 1617-35.

Lo Piccolo, "Viewpoint. The planning research agenda: plural cities, equity and rights of citizenship," Town Planning Review 81, no. 6 (2010): i-vi.

Mara and Alabaster, "A new paradigm for low-cost urban water supplies and sanitation in developing countries," Water Policy 10(2008): 119-29.

Mattingly and Winarso, "Urban Spatial Planning and Public Capital Investment: The Experience of Indonesia's Integrated Urban Infrastructure Investment Programme," (London: DPU Working Paper No. 113. Development Planning Unit, University College London., 2000).

McFarlane, "Governing the Contaminated City: Infrastructure and Sanitation in Colonial and Post-Colonial Bombay," International Journal of Urban and Regional Research 32, no. 2 (2008): 415-35.

Melosi. The sanitary city : urban infrastructure in America from colonial times to the present. (Baltimore: Johns Hopkins press, 2000).

Miller, "Support to DKI Jakarta for Wastewater Management," in Unpublished Draft Final Report (Jakarta: The Worldbank- WSP EAP, 2006).

Mitchell. Colonising Egypt. (Berkeley and Los Angeles: University California Press, 1991 [1988]).

Mulyana, Decent work in Jakarta: An integrated approach,ILO Asia-Pacific Working Paper Series (Bangkok: International Labour Organization, Regional Office for Asia and the Pacific, 2012).

$\mathrm{Ng}$, "Intellectuals and the production of space in the urban renewal process in Hong Kong and Taipei," Planning Theory and Practice 15, no. 1 (2014): 77-92. 
Niessen. Municipal Government in Indonesia. Policy, Law, and Practice of

Decentralization and Urban Spatial Planning. (Leiden: CNWS Publications, 1999).

PDPAL Jaya, Rencana Strategi Sanitasi Kota Provinsi DKI Jakarta Tahun 2010-2015

Sub Sektor Air Limbah. Disusun dalam rangka Percepatan Pembangunan Sanitasi

Perkotaan (unpublished). Jakarta, 2010.

Porter, The History of Public Health and the Modern State <P in a circle> 1994 Rodopi B.V.

Putri and Sari, "Jakarta Waterscape: From Structuring Water to 21st Century Hybrid Nature?," Nakhara, Journal of Environment and Design 6(2010): 59-74.

Quinn, "Washing Your Hair in Java," in Cleanliness and Culture. Indonesian Histories, ed. Van Dijk, K. and J.G. Taylor (Leiden: KITLV, 2011).

Ray, "Asian Capital in the Age of European Domination: The Rise of the Bazaar, 18001914," Modern Asian Studies 29, no. 3 (1995): 449-554.

Reerink. Tenure security for Indonesia's urban poor. A socio-legal study on land, decentralisation, and the rule of law in Bandung. (Leiden: Leiden University Press, 2011).

Reid, "The Structure of Cities in Southeast Asia, Fifteenth to Seventeenth Centuries," Journal of Southeast Asian Studies 11, no. 2 (1980): 235-50.

Rimmer and Dick. The City in Southeast Asia. Patterns, Processes and Policy. (Singapore: NUS Press, 2009).

Robinson, "Thinking cities through elsewhere: Comparative tactics for a more global urban studies," Progress in Human Geography 40, no. 1 (2016): 3-29.

Roy, "Urban Informality: Toward an Epistemology of Planning," Journal of the American Planning Association 71, no. 2 (2005): 147-58.

Schramm, "Flooding the sanitary city," CITY 20, no. 1 (2016): 32-51.

Silver. Planning the Megacity: Jakarta in the Twentieth Century. (London, New York: Routledge, 2008).

Taylor, "Bathing and Hygiene. Histories from the KITLV Images Archive," in Cleanliness and Culture. Indonesian Histories, ed. Van Dijk, K. and J.G. Taylor (Leiden: KITLV, 2011).

Mercy Corps Indonesia and Urban and Regional Development Institute, Urban Bulletin No.2. Summary of Land Tenure Research Findings in Jakarta. Jakarta, 2008. 
Van der Brug, "Unhealthy Batavia and the decline of the VOC in the eighteenth century " in Jakarta-Batavia. Socio-cultural Essays, ed. Grijns, K. and P.J.M. Nas (Leiden KITLV Press, 2000).

Van der Heiden, "Town planning in the Dutch Indies," Planning Perspectives 5(1990): 63-84.

Van Dijk, "Soap is the Onset of Civilization," in Cleanliness and Culture. Indonesian Histories, ed. Van Dijk, K. and J.G. Taylor (Leiden: KITLV Press, 2011).

Van Roosmalen, "Image, Style and Status: A Sketch of the Role and Impact of Private Enterprise as a Commissioner on Architecture and Urban Development in the Dutch East Indies from 1870 to 1942," Journal of Southeast Asian Architecture 6, no. 3 (2002): 61-74.

---, "Expanding grounds. The roots of spatial planning in Indonesia," in Kota lama, kota baru: Sejarah kota-kota di Indonesia sebelum dan setelah kemerdekaan (The History of the Indonesian City before and after Independence), ed. Freek Colombijn, M.B., Purnawan Basundoro, Johny Alfian Khusyairi (Yogyakarta: Ombak, 2005).

---, "For Kota and Kampong. The Emergence of Town Planning as a Discipline," in For Profit and Prosperity: The Contribution made by Dutch Engineers to Public Works in Indonesia 1800-2000, ed. Ravesteijn, W. and J. Kop (Zaltbommel and Leiden: Aprilis and KITLV, 2008).

Veering, "Nodes in the maritime network: The formation of the port system," in For Profit and Prosperity: The Contribution made by Dutch Engineers to Public Works in Indonesia 1800-2000, ed. Ravesteijn, W. and J. Kop (Zaltbommel and Leiden: Aprilis and KITLV, 2008).

Verschure. Housing and development: an evaluation of concepts and ideas with case studies focussing on housing policies and spontaneous settlements in Third World cities.: Unpublished PhD Thesis. Faculteit toegepaste wetenschappen, KU Leuven, Belgium., 1979).

Waterson. The Living House. An Anthropology of Architecture in Southeast Asia. (Oxford: Oxford University Press, 1997).

Watson, "Seeing from the South: Refocusing Urban Planning on the Globe's Central Urban Issues," Urban Studies 46, no. 11 (2009): 2259-75.

Werlin, "The Slum Upgrading Myth," Urban Studies 36, no. 9 (1999): 1523-34.

Widodo. Morphogenesis and Hybridity of Southeast Asian Coastal Cities. Edited by Ismail, R., et al., Southeast Asian Culture and Heritage in a Globalising World: Diverging Identities in a Dynamic Region. (Farnham: Ashgate, 2009). 
Yachiko Engineering, The Project for Capacity Development of Wastewater Sector through Reviewing the Wastewater Management Masterplan in DKI Jakarta in the Republic of Indonesia, Draft Final Report, Summary (Jakarta: JICA, Ministry of Public Work, DKI Jakarta, PD PAL Jaya, 2012). 